\title{
Pengolahan Air Limbah Betalaktam Menggunakan Reagen Kaporit, PAC, dan Alum Sulfat
}

\author{
Gede H. Cahyana ${ }^{1, *}$, Gilang Gumilar ${ }^{2}$, Tri Mulyani ${ }^{3}$ \\ 1,2,3Prodi Teknik Lingkungan Universitas Kebangsaan, Indonesia \\ *Koresponden email: ghcahyana@ gmail.com
}

Diterima: 23 Juni 2020

Disetujui: 29 Juni 2021

\begin{abstract}
Beta lactam antibiotics are pollutant in water bodies such as lakes and rivers. Beta lactam rings may have a negative impact on living beings in lakes and rivers. Beta lactam rings also cause resistance or bacterial resistance to antibiotics. If human beings are exposed to beta lactam ring, this could negatively impact on their health. This study attempted to break down the beta lactam rings with several chemical reagents. These reagents hydrolyze the beta lactam ring and are then analyzed using the HPLC (High Performance Liquid Chromatography) instrument. This study aims to determine the how effective the reagent for breaking the beta lactam ring. The research was conducted in three stages: preliminary research, research on reagent effectiveness , and research on $\beta$-lactamase degradation using reagents. The results showed that calcium hypochlorite was able to break the beta lactam cycle with $100 \%$ efficiency.
\end{abstract}

Keywords : antibiotic, betalactam, reagent, HPLC

\begin{abstract}
Abstrak
Antibiotik Betalaktam adalah pencemar di dalam badan air seperti danau, sungai. Cincin Betalaktam dapat mengakibatkan dampak buruk pada kehidupan di dalam air danau dan sungai. Cincin Betalaktam dapat menimbulkan resistensi atau kekebalan bakteri terhadap antibiotik. Apabila manusia terkena paparan cincin Betalaktam maka dapat berdampak buruk pada kesehatan. Penelitian ini mencoba memutus cincin Betalaktam menggunakan reagen. Reagen menghidrolisis cincin Betalaktam kemudian dianalisis dengan HPLC (High Peformance Liquid Chromatography). Penelitian bertujuan mengetahui reagen yang efisien untuk pemutus cincin Betalaktam. Ada tiga tahap dalam penelitian, yaitu pendahuluan, penelitian efisiensi reagen, dan penelitian pemecahan cincin $\beta$-lactamase menggunakan reagen. Hasil penelitian menunjukkan bahwa kalsium hipoklorit dapat memecahkan cincin Betalaktam dengan efisiensi $100 \%$.
\end{abstract}

Kata Kunci : antibiotik, Betalaktam, reagen, $H P L C$

\section{Pendahuluan}

Antibiotika (anti: lawan, bios: hidup) adalah zat kimia yang dihasilkan oleh fungi dan bakteri, memiliki khasiat mematikan atau menghambat pertumbuhan kuman, tetapi toksisitasnya kecil bagi manusia. Berdasarkan tinjauan lapangan ke pabrik farmasi, air limbah yang dihasilkan dari produksi Betalaktam ialah antibiotik golongan penisilin. Golongan penisilin memiliki persamaan sifat kimia, mekanisme kerja, farmakologi dan karakteristik imunologis dengan sefalosporin, monobaktam, karbapenem dan penghambat $\beta$-lactamase [1]. Instalasi Pengolahan Air Limbah (IPAL) di lokasi penelitian memiliki bak yang berasal dari produksi Betalaktam yang mengolah pemutusan cicin $\beta$-lactamase menggunakan hidrolisis dengan basa kuat yaitu $\mathrm{NaOH}$ sampai $\mathrm{pH} 12$ lalu bereaksi selama 30 menit untuk pemecahan cincin $\beta$-lactamase tersebut, kemudian dinetralkan dengan asam kuat HCL sampai $\mathrm{pH}$ netral.

Oleh sebab itu perlu dilakukan penelitian perihal pemutusan cincin $\beta$-lactamase untuk menekan seminimal mungkin dampak pencemaran lingkungan oleh limbah yang berasal dari limbah indutri farmasi khususnya dari air limbah produksi antibiotik (penisilin). Solusi pemecahan cincin $\beta$-lactamase selain menggunakan sodium hydroxide $(\mathrm{NaOH})$ adalah menggunakan sodium carbonate $\left(\mathrm{Na}_{2} \mathrm{CO}_{3}\right)$ atau koagulan seperti polyaluminium chloride (PAC), aluminium sulfat $\mathrm{Al}_{2}\left(\mathrm{SO}_{4}\right)_{3}$ dan calcium hypochlorite $\mathrm{Ca}\left(\mathrm{ClO}_{2}\right)$. Penelitian ini diharapkan dapat memberikan kontribusi dalam proses pengolahan air limbah farmasi khususnya limbah Betalaktam. Penelitian ini menawarkan penerapan teknologi kromatografi cair tingkat tinggi atau HPLC (High Peformance Liquid Chromatography) untuk mengetahui apakah cincin $\beta$ lactamase dalam limbah farmasi sudah aman bagi lingkungan dan jenis reagen yang efisien dalam pemutusannya. 


\section{Tinjauan Pustaka}

Setiap perusahaan farmasi pasti memiliki cara untuk menangani buangan hasil produksi obatnya agar memenuhi baku mutu yang dipersyaratkan untuk baku mutu limbah farmasi. Maka dibuatlah IPAL (Instalasi Pengolahan Air Limbah) agar tercipta lingkungan yang bersih dan sehat[2]. Antibiotik jenis penisilin pertama kali ditemukan oleh Alexander Fleming di Inggris pada tahun 1928. Temuan ini dikembangkan dan digunakan pada permulaan perang dunia II tahun 1941 ketika obat-obat antibakteri diperlukan untuk menanggulangi infeksi akibat pertempuran [3].

Mekanisme kerja antibiotik adalah (1) Menghambat biosintesis dinding sel (penisilin, sefalosporin, sikloserin, basitrasin). (2) Meninggikan permeabilitas membran sitoplasma (sefalosporin, sikloserin, basitrasin). (3) Mengganggu sintesis protein normal bakteri (tetrasiklin, kloramfenikol, eritromisin, antibiotika aminoglikosida) [4]. Umumnya antibiotik yang mempengaruhi pembentukan dinding sel atau permeabilitas membran sel bekerja bakterisida sedangkan yang bekerja pada sintesis protein, bekerja bakteriostatik. Golongan penisilin mempunyai persamaan sifat kimia, mekanisme kerja, farmakologi dan karakteristik imunologis dengan sefalosporin, monobaktam, karbapenem, dan penghambat $\beta$-lactamase. Penisilin diperoleh dari jamur Penicillium chrysogenum dari berbagai jenis yang dihasilkan. Perbedaannya terletak pada gugus samping-R (Gambar 1) [5].

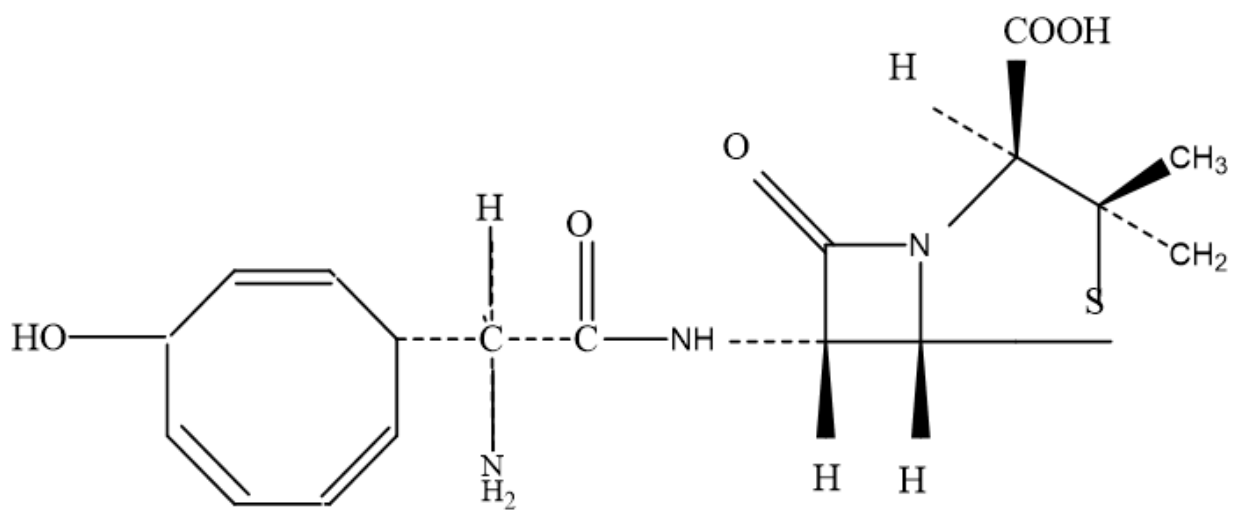

Gambar 1. Struktur rantai penisilin

Sumber: [5]

Setiap perusahaan farmasi memiliki cara khusus dalam pengolahan limbah cair dari produksi Betalaktam ( $\beta$-lactamase) agar limbah antibiotik ini aman bagi lingkungan. Inlet pengolahan air limbah Betalaktam ( $\beta$-lactamase) berasal dari sanitasi peralatan produksi dan gedung produksi, water scrubber dust collector, limbah cuci pakaian dan limbah padat Betalaktam ( $\beta$-lactamase) baik produk gagal maupun sisa proses bahan baku sisa [2].

Pengolahan limbah Betalaktam ( $\beta$-lactamase) harus ditangani secara khusus dan dipisahkan dari limbah non Betalaktam. Hal utama pengolahan air limbah Betalaktam ialah pemecahan cincin $(\beta$ lactamase) pada tangki hidrolisis dengan penambahan natrium hidroksida pada $\mathrm{pH} 12$ dengan penicilin sebagai parameter antibiotiknya. Adapun cara pemecahannya adalah (1) Hidrolisa dengan menaikkan $\mathrm{pH}$ sampai 10-12 dengan menggunakan natrium hidroksida $(\mathrm{NaOH})$. (2) Hidrolisa dengan penambahan asam ( $\mathrm{HCl})$. (3) Hidrolisa dengan penambahan merkuri klorida $\left(\mathrm{HgCl}_{2}\right)$. Alasan berbagai perusahaan memakai natrium hidroksida karena ekonomis dan ramah lingkungan serta aman bagi peralatan IPAL. Jika hidrolisis menggunakan asam dikhawatirkan merusak unit IPAL karena korosif dan jika menggunakan merkuri klorida $\left(\mathrm{HgCl}_{2}\right)$ dikhawatirkan merusak lingkungan dari sisa merkuri hasil hidrolisa.

Antibiotik disinfektan dan bakteri yang resisten sudah terdeteksi di dalam air buangan, air permukaan, dan air tanah. Antibiotik masuk ke lingkungan dari limbah farmasi, rumah sakit dan juga dalam bidang kedokteran yang spesifiknya limbah kedokteran hewan yang digunakan untuk penggerak pertumbuhan hewan dalam peternakan, budidaya ikan. Muncul kekhawatiran tingkat resistensi bakteri patogen dan efek toksisitas patogen di lingkungan akibat kekebalan antibiotik dari limbah farmasi.

Pengolahan air limbah rumah sakit dan pabrik farmasi belum didesain untuk antibiotik sehingga perlu dikembangkan teknologi alternatif untuk mengatasinya. Membran merupakan salah satu teknologi terbaru dalam pengolahan air limbah. Membran dapat diintegrasikan baik antar jenis membran maupun 
antar sistem pengolahan (hibrid membran). Membran yang digunakan adalah selulosa asetat dan komposit poliamid. Seiring dengan perkembangannya proses membran dapat dikombinasikan dengan metode membran nano filtrasi dan reverse osmosis. Proses nanofiltrasi yang dikombinasikan dengan reverse osmosis dapat memisahkan komponen pengotor yang mengandung residu obat-obatan sebesar 94\% $100 \%$. Hibrid membran nanofiltrasi dan reverse osmosis adalah teknologi membran yang terkini dan belum banyak dimanfaatkan dalam pengolahan air limbah rumah sakit dan pabrik farmasi [6].

Amoksisilin dalam limbah farmasi memiliki dampak toksik terhadap alga dan organisme rendah lainnya dalam jaring makanan. Adsorpsi, sebagai proses yang efisien untuk menurunkan kadar amoksisilin dari air khususnya dengan bentonit dan karbon aktif sebagai adsorban. Karbon aktif telah banyak digunakan untuk menghilangkan kontaminan organik dalam air limbah skala industri. Aplikasi ini memiliki kapasitas adsorpsi yang tinggi nilai efisiensinya untuk menghilangkan zat organik tertentu. Dalam beberapa aplikasi, efisiensi penurunan nilai zat organik dalam air dapat mencapai $100 \%$. Oleh karena itu, adsorban alternatif yang murah dan tersedia dalam jumlah yang banyak secara alami, bentonit. Bentonit sebagai alternatif adsorban dapat dimanfaatkan untuk menyerap amoksisilin dari air limbah sintetis. Sebelum digunakan sebagai adsorban, bentonit dan karbon aktif disiapkan dengan ukuran partikel 60/80 mesh. Analisis bentonit (murni dan setelah adsorpsi) dilakukan dengan spektrofotometer serapan atom [7].

Antibiotik adalah kontaminan berbahaya karena efek buruknya pada hewan dan tumbuhan air serta manusia. Masalah yang mungkin ditimbulkan oleh adanya antibiotik di lingkungan ialah resistensi terhadap bakteri. Metode pemecahan cincin $\beta$-lactamase dapat dilakukan dengan foto-fenton yang menghasilkan pelepasan dan mineralisasi karbon organik dan nitrogen dalam molekul antibiotik. Pereaksi fenton didasarkan pada radikal hidroksil $\left(\mathrm{OH}^{-}\right)$yang diproduksi oleh dekomposisi katalitik hidrogen peroksida dalam reaksi dengan ion besi. Dalam proses foto-fenton, reaksi menghasilkan radikal hidroksil. Sudah ada studi tentang pengolahan limbah cair amoksisilin dan formulasi penicillin oleh AOP. Kinetika reaksi ozonasi amoksisilin telah dipelajari. Namun, tidak ada penelitian tentang degradasi amoksisilin, antibiotik ampicillin dan cloxacillin dalam larutan air oleh foto-fenton [8].

Belum ada konsentrasi aman antibiotik yang masuk ke lingkungan. Apabila lingkungan yang tercemar oleh bakteri yang resisten masuk ke dalam tubuh manusia dampaknya manusia terpapar, maka sulit sembuh karena bakteri yang kuat terhadap antibiotik, bagi orang yang alergi antibiotik akan mengalami ruam dan gatal-gatal pada kulitnya [9]. Resistensi terhadap antibiotik adalah kekebalan bakteri pada jenis antibiotik tertentu. Jika bakteri di lingkungan terpapar terus menerus oleh limbah antibiotik akan berdampak negatif bagi lingkungan dan makhluk hidup. Peneliti mengusulkan pemantauan pada industri antibiotik, rumah sakit dan lainnya yang menghasilkan limbah antibiotik. Resistensi antibiotik pada bakteri patogen merupakan tantangan di seluruh dunia yang terkait dengan tingginya angka resisten si. Pola resisten pada bakteri gram negatif dan gram positif menghasilkan infeksi yang sulit diobati karena identifikasi awal dari kerentanan resisten antibiotik [10].

Kromatografi adalah teknik pemisahan satu atau lebih komponen dari suatu sampel yang dibawa fase gerak melewati fase diam (dapat berbentuk padat atau cairan). Istilah kromatografi berasal dari gabungan kata "chroma" (warna) dan "graphein" (menuliskan). Kromatografi Cair Kinerja Tinggi atau High Performance Liquid Chromatography (HPLC) adalah kromatografi cair kolom modern, teori dasarnya bukanlah baru tetapi pengembangan dari kromatografi cair kolom klasik. Kemajuan dalam teknologi kolom, pompa tekanan tinggi dan detektor yang peka telah menyebabkan perubahan kromatografi kolom cair menjadi suatu sistem pemisahan yang cepat dan efisien. Pada KCKT diperkenalkan penggunaan fase diam yang berdiameter kecil dalam kolom yang efisien. Teknologi kolom partikel kecil $(3-5 \mu \mathrm{m})$ ini memerlukan sistem pompa bertekanan tinggi yang mampu mengalirkan fase gerak dengan tekanan tinggi agar tercapai laju aliran 1-2 ml/menit. Oleh karena sampel yang digunakan sangat kecil $(<20 \mu \mathrm{g})$ maka diperlukan detektor yang peka. Dengan teknologi ini, pemisahan berlangsung sangat cepat dengan daya pisah sangat tinggi [11]. 


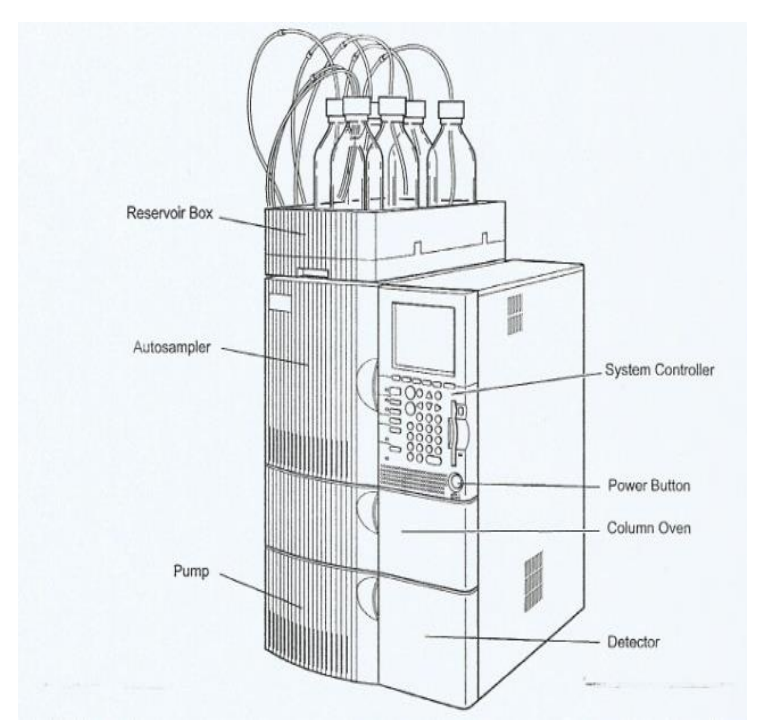

Gambar 2. Instrumen HPLC

Sumber: [11]

\section{Metode Penelitian}

Penelitian ini adalah penelitian skala laboratorium untuk menganalisis efisiensi pemecahan cincin $\beta$ lactamase air limbah produksi antibiotik dengan metode instrumen $\mathrm{HPLC}$ dengan reagen $\mathrm{NaOH}, \mathrm{Na}_{2} \mathrm{CO}_{3}$, $\mathrm{Al}_{2}\left(\mathrm{SO}_{4}\right)_{3}$, PAC dan $\mathrm{Ca}\left(\mathrm{ClO}_{2}\right)$. Penelitian terdiri dari tiga tahap: penelitian pendahuluan, analisis laboratorium untuk mengetahui air limbah Betalaktam yang mengandung cincin $\beta$-lactamase. Penelitian kedua yaitu mencari reagen yang efisien dan efektif untuk memecah cincin $\beta$-lactamase. Penelitian ketiga yaitu pemecahan cincin $\beta$-lactamase menggunakan koagulan.

Variabel bebas yaitu variabel yang akan dilihat pengaruhnya terhadap variabel tidak bebas. Sebagai independen variable adalah reagen kimia untuk netralisasi $\mathrm{NaOH}, \mathrm{Na}_{2} \mathrm{CO}_{3}$, koagulan $\mathrm{Al}_{2}\left(\mathrm{SO}_{4}\right)_{3}, \mathrm{PAC}$ dan $\mathrm{Ca}\left(\mathrm{ClO}_{2}\right)$. Variabel dependen atau variabel yang dipengaruhi adalah cincin $\beta$-lactamase dalam air limbah antibiotik. Variabel pengganggu adalah variabel yang dapat mempengaruhi variabel dependen. Variabel pengganggu adalah $\mathrm{pH}$. Pengambilan sampel dilakukan secara grab sampel (sampel sesaat). Proses penelitian mulai dari temuan masalah di pabrik farmasi kemudian dikuatkan dengan studi pustaka. Tahap persiapan alat dan bahan, identifikasi karakteristik jenis-jenis antibiotik yang ada di dalam air limbah Betalaktam dan konsentrasi cincin $\beta$-lactamase dalam air limbah tersebut. Hal ini untuk memperoleh data primer karakteristik awal air limbah Betalaktam.

\subsection{Bahan}

Air murni (purified water), kalium fosfat monobasa $\left(\mathrm{KH}_{2} \mathrm{PO}_{4}\right)$, asetonitril digunakan untuk campuran pembuatan fase gerak dalam sistem HPLC. Kalium hidroksida $(\mathrm{KOH})$ digunakan untuk mengatur $\mathrm{pH}$ fase gerak menjadi 5. Working standard Amoxicilin digunakan sebagai standar pembanding dengan sampel air limbah Betalaktam yang menggandung cincin $\beta$-lactamase. Natrium hidroksida $(\mathrm{NaOH})$, natrium karbonat $\left(\mathrm{Na}_{2} \mathrm{CO}_{3}\right)$, PAC, kalsium hypoklorit $\mathrm{Ca}\left(\mathrm{ClO}_{2}\right)$, alumunium sulfat $\mathrm{Al}_{2}\left(\mathrm{SO}_{4}\right)_{3}$ digunakan sebagai reagen pemecah cincin $\beta$-lactamase.

\subsection{Alat}

Botol $100 \mathrm{ml}$, neraca analitis, pH-meter, HPLC, pompa vacum, kolom HPLC ukuran $150 \mathrm{~mm}$ x 4.6 $\mathrm{cm}$ (L1 pendek), magnetic stirrer, labu ukur $50 \mathrm{ml}$.

\section{Hasil dan Pembahasan}

Pada penelitian ini identifikasi karakteristik dan konsentrasi awal nilai cincin $\beta$-lactamase dengan penicilin sebagai parameter antibiotiknya. Sampel yang dianalisis berasal dari pengolahan limbah farmasi sebagaimana dalam Tabel 1. 
Tabel 1. Uji pendahuluan air limbah Betalaktam

\begin{tabular}{cccc}
\hline $\begin{array}{c}\text { Tanggal } \\
\text { Pengujian }\end{array}$ & $\begin{array}{c}\text { Luas Area } \\
\text { Standar }\end{array}$ & $\begin{array}{c}\text { Luas Area } \\
\text { Sampel }\end{array}$ & $\begin{array}{c}\text { Konsentrasi } \\
\text { Awal }(\mathrm{ppm})\end{array}$ \\
\hline $\begin{array}{c}\text { 01 Oktober } \\
2018\end{array}$ & 9.741 .134 & 1.039 .157 & 106,68 \\
\hline
\end{tabular}

Tabel 2. Pemutusan cincin $\beta$-lactamase menggunakan $\mathrm{NaOH}$

\begin{tabular}{|c|c|c|c|c|}
\hline No. & $\begin{array}{c}\text { Tanggal } \\
\text { Sampling }\end{array}$ & $\begin{array}{c}\text { Waktu } \\
\text { Sampling }\end{array}$ & $\begin{array}{c}\text { Konsentrasi } \\
\text { standar } \\
(\mathrm{ppm})\end{array}$ & $\begin{array}{c}\text { Konsentrasi } \\
\text { sampel } \\
(\mathrm{ppm})\end{array}$ \\
\hline 1. & 08 Okt 2018 & 10.00 & 91,24 & 0,57 \\
\hline 2. & 09 Okt 2018 & 11.00 & 91,35 & 0,55 \\
\hline 3. & 10 Okt 2018 & 10.30 & 92,14 & 0,55 \\
\hline 4. & 11 Okt 2018 & 10.25 & 91,53 & 0,55 \\
\hline 5. & 12 Okt 2018 & 10.40 & 91,42 & 0,54 \\
\hline 6. & 13 Okt 2018 & 11.00 & 91,41 & 0,53 \\
\hline 7. & 14 Okt 2018 & 10.45 & 91,32 & 0,53 \\
\hline 8. & 15 Okt 2018 & 10.15 & 91,3 & 0,53 \\
\hline 9. & 16 Okt 2018 & 11.15 & 91,18 & 0,53 \\
\hline 10. & 17 Okt 2018 & 10.00 & 91,07 & 0,53 \\
\hline 11. & 18 Okt 2018 & 11.00 & 94,52 & 0,53 \\
\hline 12. & 19 Okt 2018 & 10.25 & 94,33 & 0,53 \\
\hline 13. & 20 Okt 2018 & 10.30 & 94,34 & 0,54 \\
\hline 14. & 21 Okt 2018 & 10.35 & 94,24 & 0,53 \\
\hline 15. & 22 Okt 2018 & 10.40 & 94,22 & 0,54 \\
\hline 16. & 23 Okt 2018 & 10.20 & 94,15 & 0,53 \\
\hline 17. & 24 Okt 2018 & 10.45 & 94,14 & 0,53 \\
\hline 18. & 25 Okt 2018 & 11.00 & 94,16 & 0,53 \\
\hline 19. & 26 Okt 2018 & 10.45 & 94,19 & 0,53 \\
\hline 20. & 27 Okt 2018 & 10.25 & 94,2 & 0,53 \\
\hline 21. & 28 Okt 2018 & 10.45 & 94,21 & 0,57 \\
\hline 22. & 29 Okt 2018 & 11.00 & 94,23 & 0,57 \\
\hline 23. & 30 Okt 2018 & 10.45 & 94,21 & 0,57 \\
\hline 24. & 31 Okt 2018 & 11.00 & 94,16 & 0,57 \\
\hline 25. & 01 Nov 2018 & 10.45 & 94,06 & 0,57 \\
\hline 26. & 02 Nov 2018 & 11.00 & 94,08 & 0,56 \\
\hline 27. & 03 Nov 2018 & 10.00 & 94,11 & 0,57 \\
\hline 28. & 04 Nov 2018 & 10.45 & 94,09 & 0,56 \\
\hline 29. & 05 Nov 2018 & 10.40 & 94,02 & 0,56 \\
\hline 30. & 06 Nov 2018 & 11.00 & 93.97 & 0,56 \\
\hline
\end{tabular}

Berdasarkan Tabel 2 konsentrasi Betalaktam setelah penambahan $\mathrm{NaOH}$ hasilnya cukup konsisten serta penurunannya cukup signifikan, nilai terkecil $0,53 \mathrm{ppm}$ dan terbesar $0,57 \mathrm{ppm}$ dan eefisiensinya $99,42 \%$. Hal ini disebabkan oleh konsentrasi cincin $\beta$-lactamase di dalam penisilin terhidrolisis oleh basa kuat yaitu dengan cara reaksi nukleofilik [11]. Akan tetapi karena $\mathrm{OH}^{-}$pada $\mathrm{NaOH}$ sangat kuat daya ikatnya terhadap struktur dalam penisilin, maka serangan $\mathrm{OH}^{-t e r h a d a p} \operatorname{cincin} \beta$-lactamase tidak hanya pada gugus keton di cincin $\beta$-lactamase, sebagian $\mathrm{OH}^{-}$menyerang gugus lainnya pada struktur penisilin yang mengakibatkan cincin $\beta$-lactamase dalam air limbah farmasi belum terpecah.kan [12].

Pada penelitian yang dilakukan oleh [6] diperoleh hasil tentang penurunan antibiotik dalam air limbah akan tetapi jenis antibiotik yang diteliti adalah ciproloxacin bukan golongan penisilin ataupun amoxicilin. Alatnya adalah membran nanofiltrasi dan reverse osmosis yang dibantu dengan tekanan sebesar 80 psi untuk menghilangkan air dari kontaminan organik dan anorganik yang mampu mengurangi konsentrasi ciproloxacin senilai 98,40\%. Namun demikian, penggunaan membran ini membutuhkan biaya tinggi. 
Tabel 3. Pemutusan cincin $\beta$-lactamase menggunakan $\mathrm{Na}_{2} \mathrm{CO}_{3}$

\begin{tabular}{llllc}
\hline No. & Sampling & $\begin{array}{c}\text { Waktu } \\
\text { Sampling }\end{array}$ & $\begin{array}{c}\text { Konsentrasi } \\
\text { standar } \\
\text { (ppm }\end{array}$ & $\begin{array}{c}\text { Konsentrasi } \\
\text { sampel } \\
\text { (ppm) }\end{array}$ \\
\hline 1. & 08 Okt 2018 & 10.00 & 91,24 & 0,29 \\
2. & 09 Okt 2018 & 11.00 & 91,35 & 0,28 \\
3. & 10 Okt 2018 & 10.30 & 92,14 & 0,29 \\
4. & 11 Okt 2018 & 10.25 & 91,53 & 0,28 \\
5. & 12 Okt 2018 & 10.40 & 91,42 & 0,28 \\
6. & 13 Okt 2018 & 11.00 & 91,41 & 0,28 \\
7. & 14 Okt 2018 & 10.45 & 91,32 & 0,27 \\
8. & 15 Okt 2018 & 10.15 & 91,3 & 0,27 \\
9. & 16 Okt 2018 & 11.15 & 91,18 & 0,27 \\
10. & 17 Okt 2018 & 10.00 & 91,07 & 0,27 \\
11. & 18 Okt 2018 & 11.00 & 94,52 & 0,27 \\
12. & 19 Okt 2018 & 10.25 & 94,33 & 0,27 \\
13. & 20 Okt 2018 & 10.30 & 94,34 & 0,27 \\
14. & 21 Okt 2018 & 10.35 & 94,24 & 0,28 \\
15. & 22 Okt 2018 & 10.40 & 94,22 & 0,27 \\
16. & 23 Okt 2018 & 10.20 & 94,15 & 0,28 \\
17. & 24 Okt 2018 & 10.45 & 94,14 & 0,28 \\
18. & 25 Okt 2018 & 11.00 & 94,16 & 0,28 \\
19. & 26 Okt 2018 & 10.45 & 94,19 & 0,28 \\
20. & 27 Okt 2018 & 10.25 & 94,2 & 0,28 \\
21. & 28 Okt 2018 & 10.45 & 94,21 & 0,30 \\
22. & 29 Okt 2018 & 11.00 & 94,23 & 0,31 \\
23. & 30 Okt 2018 & 10.45 & 94,21 & 0,30 \\
24. & 31 Okt 2018 & 11.00 & 91,24 & 0,30 \\
25. & 01 Nov 2018 & 10.45 & 94,16 & 0,30 \\
26. & 02 Nov 2018 & 11.00 & 94,06 & 0,31 \\
27. & 03 Nov 2018 & 10.00 & 94,08 & 0,30 \\
28. & 04 Nov 2018 & 10.45 & 94,11 & 0,30 \\
29. & 05 Nov 2018 & 10.40 & 94,09 & 0,31 \\
30. & 06 Nov 2018 & 11.00 & 94,02 & 0,30 \\
\hline & & & & \\
\hline
\end{tabular}

Berdasarkan Tabel 3 konsentrasi air limbah Betalaktam setelah penambahan $\mathrm{Na}_{2} \mathrm{CO}_{3}$ hasilnya cukup konsisten serta penurunannya cukup signifikan, terkecil 0,27 ppm dan terbesar 0,29 ppm. Efisiensinya 99,70\%. Hal ini karena cincin $\beta$-lactamase di dalam penisilin terhidrolisis oleh basa lemah dengan cara reaksi nukleofilik[11]. Akan tetapi basa yang digunakan sifatnya basa lemah jadi $\mathrm{OH}^{-}$dalam $\mathrm{Na}_{2} \mathrm{CO}_{3}$ tidak terionisasi sempurna dalam air, maka serangan $\mathrm{OH}^{-}$terhadap gugus keton yang ada di struktur cincin $\beta$-lactamase tidak sebaik basa kuat meskipun serangannya sudah terfokus pada cincin $\beta$-lactamase. Oleh sebab itu $\mathrm{OH}^{-}$dalam $\mathrm{Na}_{2} \mathrm{CO}_{3}$ kurang kuat dalam menghidrolisis semua cincin $\beta$-lactamase dalam air limbah Betalaktam [12].

Tabel 4. Pemutusan cincin $\beta$-lactamase menggunakan PAC

\begin{tabular}{lcccc}
\hline No. & $\begin{array}{c}\text { Tanggal } \\
\text { Sampling }\end{array}$ & $\begin{array}{c}\text { Waktu } \\
\text { Sampling }\end{array}$ & $\begin{array}{c}\text { Konsentrasi } \\
\text { standar } \\
(\mathrm{ppm}\end{array}$ & $\begin{array}{c}\text { Konsentrasi } \\
\text { sampel } \\
(\mathrm{ppm})\end{array}$ \\
\hline 1. & 08 Okt 2018 & 10.00 & 91,24 & 0,15 \\
2. & 09 Okt 2018 & 11.00 & 91,35 & 0,13 \\
3. & 10 Okt 2018 & 10.30 & 92,14 & 0,13 \\
4. & 11 Okt 2018 & 10.25 & 91,53 & 0,13 \\
5. & 12 Okt 2018 & 10.40 & 91,42 & 0,13 \\
6. & 13 Okt 2018 & 11.00 & 91,41 & 0,13 \\
7. & 14 Okt 2018 & 10.45 & 91,32 & 0,14 \\
8. & 15 Okt 2018 & 10.15 & 91,3 & 0,14 \\
9. & 16 Okt 2018 & 11.15 & 91,18 & 0,13 \\
10. & 17 Okt 2018 & 10.00 & 91,07 & 0,13 \\
11. & 18 Okt 2018 & 11.00 & 94,52 & 0,14 \\
12. & 19 Okt 2018 & 10.25 & 94,33 & 0,14 \\
\hline & & 2071 & &
\end{tabular}




\begin{tabular}{lllll}
\hline 13. & 20 Okt 2018 & 10.30 & 94,34 & 0,14 \\
14. & 21 Okt 2018 & 10.35 & 94,24 & 0,14 \\
15. & 22 Okt 2018 & 10.40 & 94,22 & 0,14 \\
16. & 23 Okt 2018 & 10.20 & 94,15 & 0,14 \\
17. & 24 Okt 2018 & 10.45 & 94,14 & 0,14 \\
18. & 25 Okt 2018 & 11.00 & 94,16 & 0,13 \\
19. & 26 Okt 2018 & 10.45 & 94,19 & 0,14 \\
20. & 27 Okt 2018 & 10.25 & 94,2 & 0,14 \\
21. & 28 Okt 2018 & 10.45 & 94,21 & 0,15 \\
22. & 29 Okt 2018 & 11.00 & 94,23 & 0,15 \\
23. & 30 Okt 2018 & 10.45 & 94,21 & 0,15 \\
24. & 31 Okt 2018 & 11.00 & 91,24 & 0,15 \\
25. & 01 Nov 2018 & 10.45 & 94,16 & 0,16 \\
26. & 02 Nov 2018 & 11.00 & 94,06 & 0,15 \\
27. & 03 Nov 2018 & 10.00 & 94,08 & 0,15 \\
28. & 04 Nov 2018 & 10.45 & 94,11 & 0,15 \\
29. & 05 Nov 2018 & 10.40 & 94,09 & 0,15 \\
30. & 06 Nov 2018 & 11.00 & 94,02 & 0,15 \\
\hline
\end{tabular}

Berdasarkan Tabel 4 konsentrasi air limbah Betalaktam setelah penambahan PAC hasilnya cukup konsisten serta penurunannya cukup signifikan, terkecil $0,13 \mathrm{ppm}$ dan terbesar $0,15 \mathrm{ppm}$. Hasil ini efisiensinya cukup baik yaitu $99,85 \%$. Hal ini disebabkan oleh cincin $\beta$-lactamase di dalam penisilin terhidrolisis oleh asam dengan cara reaksi nukleofilik [12].

Dalam suasana asam cincin $\beta$-lactamase akan terhidrolisis optimal pada $\mathrm{pH}$ di bawah 3 , ion $\mathrm{H}^{+}$ menyebabkan protonasi atom nitrogen pada cincin $\beta$-lactamase, diikuti serangan nukleofilik dari atom oksigen asli pada atom $\mathrm{C}$ karbonil $\beta$-lactamase lalu cincin $\beta$-lactamase terbuka dan terjadi destabilisasi cincin tiadzolidin sehingga cincin terbuka membentuk asam penisilen, karena asam yang digunakan jenisnya asam lemah $\mathrm{pH} 4,5$ maka serangan $\mathrm{H}^{+}$terhadap gugus keton yang ada dalam struktur cincin $\beta$ lactamase kurang kuat dalam menghidrolisis semua kandungan cincin tersebut sehingga mengakibatkan kandungan cincin tersebut masih ada di dalam air limbah dalam konsentrasi kecil [14].

Tabel 5. Pemutusan cincin $\beta$-lactamase menggunakan Aluminium Sulfat

\begin{tabular}{|c|c|c|c|c|}
\hline No. & $\begin{array}{l}\text { Tanggal } \\
\text { Sampling }\end{array}$ & $\begin{array}{c}\text { Waktu } \\
\text { Sampling }\end{array}$ & $\begin{array}{l}\text { Konsentrasi } \\
\text { standar } \\
(\mathrm{ppm})\end{array}$ & $\begin{array}{l}\text { Konsentrasi sampel } \\
\text { (ppm) }\end{array}$ \\
\hline 1. & 08 Okt 2018 & 10.00 & 91,24 & 0,10 \\
\hline 2. & 09 Okt 2018 & 11.00 & 91,35 & 0,08 \\
\hline 3. & 10 Okt 2018 & 10.30 & 92,14 & 0,08 \\
\hline 4. & 11 Okt 2018 & 10.25 & 91,53 & 0,08 \\
\hline 5. & 12 Okt 2018 & 10.40 & 91,42 & 0,08 \\
\hline 6. & 13 Okt 2018 & 11.00 & 91,41 & 0,09 \\
\hline 7. & 14 Okt 2018 & 10.45 & 91,32 & 0,08 \\
\hline 8. & 15 Okt 2018 & 10.15 & 91,3 & 0,08 \\
\hline 9. & 16 Okt 2018 & 11.15 & 91,18 & 0,08 \\
\hline 10. & 17 Okt 2018 & 10.00 & 91,07 & 0,08 \\
\hline 11. & 18 Okt 2018 & 11.00 & 94,52 & 0,08 \\
\hline 12. & 19 Okt 2018 & 10.25 & 94,33 & 0,09 \\
\hline 13. & 20 Okt 2018 & 10.30 & 94,34 & 0,09 \\
\hline 14. & 21 Okt 2018 & 10.35 & 94,24 & 0,08 \\
\hline 15. & 22 Okt 2018 & 10.40 & 94,22 & 0,08 \\
\hline 16. & 23 Okt 2018 & 10.20 & 94,15 & 0,08 \\
\hline 17. & 24 Okt 2018 & 10.45 & 94,14 & 0,08 \\
\hline 18. & 25 Okt 2018 & 11.00 & 94,16 & 0,08 \\
\hline 19. & 26 Okt 2018 & 10.45 & 94,19 & 0,08 \\
\hline 20. & 27 Okt 2018 & 10.25 & 94,2 & 0,08 \\
\hline 21. & 28 Okt 2018 & 10.45 & 94,21 & 0,09 \\
\hline 22. & 29 Okt 2018 & 11.00 & 94,23 & 0,09 \\
\hline 23. & 30 Okt 2018 & 10.45 & 94,21 & 0,09 \\
\hline 24. & 31 Okt 2018 & 11.00 & 91,24 & 0,09 \\
\hline 25. & 01 Nov 2018 & 10.45 & 94,16 & 0,09 \\
\hline 26. & 02 Nov 2018 & 11.00 & 94,06 & 0,09 \\
\hline
\end{tabular}




\begin{tabular}{lllll}
\hline 27. & 03 Nov 2018 & 10.00 & 94,08 & 0,10 \\
28. & 04 Nov 2018 & 10.45 & 94,11 & 0,09 \\
29. & 05 Nov 2018 & 10.40 & 94,09 & 0,09 \\
30. & 06 Nov 2018 & 11.00 & 94,02 & 0,09 \\
\hline
\end{tabular}

Berdasarkan Tabel 5 konsentrasi air limbah Betalaktam setelah penambahan $\mathrm{Al}_{2}(\mathrm{SO} 4)_{3}$ hasilnya cukup konsisten dan penurunannya cukup signifikan, terkecil $0,08 \mathrm{ppm}$ dan hasil terbesar $0,10 \mathrm{ppm}$ serta efisiensinya $99,91 \%$. Hal ini karena konsentrasi cincin $\beta$-lactamase di dalam penisilin terhidrolisis oleh asam lemah dengan cara reaksi nukleofilik. Berbeda dengan $\mathrm{PAC}, \mathrm{Al}_{2}(\mathrm{SO} 4)_{3}$ lebih kuat serangannya terhadap cincin $\beta$-lactamase, karena $\mathrm{Al}_{2}(\mathrm{SO} 4)_{3}$ yang dilarutkan dalam air melepaskan $6 \mathrm{H}^{+}[15]$. Nilai $\mathrm{pH}$ nya 3,5 , serangan $\mathrm{H}^{+}$terhadap gugus keton yang ada di dalam struktur cincin $\beta$-lactamase lebih kuat dibandingkan dengan PAC, karena $\mathrm{pH}$ optimal untuk pemecahan cincin $\beta$-lactamase di bawah 3 , ion $\mathrm{H}^{+}$ menyebabkan protonasi atom nitrogen pada cincin $\beta$-lactamase, diikuti serangan nukleofilik dari atom oksigen asli pada atom $\mathrm{C}$ karbonil $\beta$-lactamase lalu cincin $\beta$-lactamase terbuka dan terjadi destabilisasi cincin tiadzolidin sehingga cincin terbuka membentuk asam penisilenat. Hal ini menyebabkan konsentrasi air limbah Betalakatam hasilnya mendekati angka 0 karena $\mathrm{pH}$ alumunium sulfat sudah mendekati nilai optimal pada pemecahan cincin $\beta$-lactamase [14].

Tabel 6. Pemutusan cincin $\beta$-lactamase menggunakan kaporit

\begin{tabular}{|c|c|c|c|c|}
\hline No. & $\begin{array}{c}\text { Tanggal } \\
\text { Sampling }\end{array}$ & $\begin{array}{c}\text { Waktu } \\
\text { Sampling }\end{array}$ & $\begin{array}{c}\text { Konsentrasi } \\
\text { standar } \\
\text { (ppm }\end{array}$ & $\begin{array}{c}\text { Konsentrasi } \\
\text { sampel } \\
\text { (ppm) }\end{array}$ \\
\hline 1. & 08 Okt 2018 & 10.00 & 91,24 & 0,00 \\
\hline 2. & 09 Okt 2018 & 11.00 & 91,35 & 0,00 \\
\hline 3. & 10 Okt 2018 & 10.30 & 92,14 & 0,00 \\
\hline 4. & 11 Okt 2018 & 10.25 & 91,53 & 0,00 \\
\hline 5. & 12 Okt 2018 & 10.40 & 91,42 & 0,00 \\
\hline 6. & 13 Okt 2018 & 11.00 & 91,41 & 0,00 \\
\hline 7. & 14 Okt 2018 & 10.45 & 91,32 & 0,00 \\
\hline 8. & 15 Okt 2018 & 10.15 & 91,30 & 0,00 \\
\hline 9. & 16 Okt 2018 & 11.15 & 91,18 & 0,00 \\
\hline 10. & 17 Okt 2018 & 10.00 & 91,07 & 0,00 \\
\hline 11. & 18 Okt 2018 & 11.00 & 94,52 & 0,00 \\
\hline 12. & 19 Okt 2018 & 10.25 & 94,33 & 0,00 \\
\hline 13. & 20 Okt 2018 & 10.30 & 94,34 & 0,00 \\
\hline 14. & 21 Okt 2018 & 10.35 & 94,24 & 0,00 \\
\hline 15. & 22 Okt 2018 & 10.40 & 94,22 & 0,00 \\
\hline 16. & 23 Okt 2018 & 10.20 & 94,15 & 0,00 \\
\hline 17. & 24 Okt 2018 & 10.45 & 94,14 & 0,00 \\
\hline 18. & 25 Okt 2018 & 11.00 & 94,16 & 0,00 \\
\hline 19. & 26 Okt 2018 & 10.45 & 94,19 & 0,00 \\
\hline 20. & 27 Okt 2018 & 10.25 & 94,20 & 0,00 \\
\hline 21. & 28 Okt 2018 & 10.45 & 94,21 & 0,00 \\
\hline 22. & 29 Okt 2018 & 11.00 & 94,23 & 0,00 \\
\hline 23. & 30 Okt 2018 & 10.45 & 94,21 & 0,00 \\
\hline 24. & 31 Okt 2018 & 11.00 & 91,24 & 0,00 \\
\hline 25. & 01 Nov 2018 & 10.45 & 94,16 & 0,00 \\
\hline 26. & 02 Nov 2018 & 11.00 & 94,06 & 0,00 \\
\hline 27. & 03 Nov 2018 & 10.00 & 94,08 & 0,00 \\
\hline 28. & 04 Nov 2018 & 10.45 & 94,11 & 0,00 \\
\hline 29. & 05 Nov 2018 & 10.40 & 94,09 & 0,00 \\
\hline 30. & 06 Nov 2018 & 11.00 & 94,02 & 0,00 \\
\hline
\end{tabular}

Pada Tabel 6 ditampilkan hasil penurunan pemecahan cincin $\beta$-lactamase dengan penambahan calcium hypoklorit. Hasil pada Tabel 6 menunjukkan bahwa data sangat konsisten dari konsentrasi air limbah awal yang berkonsentrasi 91 - 94,52 ppm menjadi 0 ppm dan efisiensinya 100\% menghilangkan cincin $\beta$-lactamase dari air limbah farmasi produksi Betalaktam. Hasil ini sangat efisien dibandingkan dengan semua reagen yang digunakan pada saat penelitian untuk memecah cicin $\beta$-lactamase. Hal ini disebabkan oleh calcium hypoklorit yang berguna untuk inaktivasi patogen dapat merusak sepenuhnya 
kandungan cincin $\beta$-lactamase dalam air limbah Betalaktam karena cicin $\beta$-lactamase tersusun dari hasil metabolisme sekunder mikroorganisme dari bakteri [16].

Tabel 7. Rekapitulasi pemutusan cincin $\beta$-lactamase

\begin{tabular}{cc}
\hline Jenis Reagen & Efisiensi (\%) \\
\hline (Sodium hydroxide) $\mathrm{NaOH}$ & $99,42 \%$ \\
(Sodium carbonate) $\mathrm{Na}_{2} \mathrm{CO}_{3}$ & $99,70 \%$ \\
(Polyalumunium Chloride) $\mathrm{PAC}$ & $99,85 \%$ \\
(Aluminium Sulfat) $\mathrm{Al}_{2}\left(\mathrm{SO}_{4}\right)_{3}$ & $99,91 \%$ \\
(Calcium Hypochlorite) & $100 \%$ \\
$\mathrm{Ca}\left(\mathrm{ClO}_{2}\right)$ (kaporit) & \\
\hline
\end{tabular}

Pada Tabel 7 diberikan rekapitulasi, yaitu efisiensi pemecahan cincin $\beta$-lactamase setiap reagen. Reagen calcium hypoklorit memiliki efisiensi pemecahan cincin $\beta$-lactamase terbesar jika dibandingkan dengan reagen lain seperti sodium hydroxide $(\mathrm{NaOH})$, sodium carbonate $\left(\mathrm{Na}_{2} \mathrm{CO}_{3}\right)$, polyaluminum chloride (PAC), alumunium sulfat. Penambahan kaporit pada air limbah Betalaktam yaitu senilai $1 \%$ diperoleh efisiensi $100 \%$. Hal ini karena calcium hypoklorit mampu memecahkan kandungan cincin $\beta$-lactamase dalam air limbah. Hal ini karena calcium hypoklorit mempunyai daya bunuh bakteri yang baik sehingga mengakibatkan antibiotik yang terbuat dari hasil fermentasi bakteri mati oleh serangan calcium hypoklorit secara biologi.

\section{Kesimpulan}

Proses pengujian pemutusan cincin $\beta$-lactamase efektif dengan metode instrumen HPLC karena dapat mendeteksi hasil pemecahan cincin $\beta$-lactamase dengan cara dibandingkan dengan waktu detensi standar amoxicilin yang telah diketahui konsentrasi dan kemurniannya dengan benar. Proses pemecahan cincin $\beta$-lactamase menggunakan beberapa reagen yaitu $\mathrm{NaOH}, \mathrm{Na}_{2} \mathrm{CO}_{3}, \mathrm{PAC}$ (polyaluminuum chloride, alum sulfat (tawas) $\mathrm{Al}_{2}\left(\mathrm{SO}_{4}\right)_{3}$, dan (calcium hypoklorit) $\mathrm{Ca}\left(\mathrm{ClO}_{2}\right)$. Hasil yang paling efisien adalah menggunakan kaporit $\mathrm{Ca}\left(\mathrm{ClO}_{2}\right)$ karena mampu menurunkan konsentrasi cincin $\beta$-lactamase dalam air limbah Betalaktam dari 106,68 ppm menjadi 0 ppm.

\section{Daftar Pustaka}

[1] Katzung, B. G (2012). Basic and Clinical Pharmacology. Edisi 10. Jakarta, Indonesia: EGC.

[2] Sumiyati, \& Prabarani, (2008). Pengolahan Limbah Cair dan Limbah Betalaktam PT Phapros, Tbk Semarang. Jurnal Presipitasi, 5, 22-30.

[3] Tjay, T. H. (2006). Obat-Obat Penting Khasiat, Penggunaan dan Efek-Efek Sampingnya. Edisi ke 6. Jakarta, Indonesia : PT.Elex Media Komputindo.

[4] Mutschler, E. (1991). Dinamika Obat: Farmakologi dan Toksikologi. Edisi ke 5. Bandung, Indonesia: Institut Teknologi Bandung.

[5] Depkes RI. (2014). Farmakope Indonesia. Edisi 5. Jakarta, Indonesia: Departemen Kesehatan Republik Indonesia.

[6] Kurniawan, I., Nasir, S., Hermasyah., Mardiyanto. (2017). Kinerja Proses Hibrid Membran (Nanofiltrasi-Reverse Osmosis) dalam Pengolahan Air Mengandung Ciprofloxacin Antibiotik. Seminar Nasional AvoER.

[7] Putra, E. K., Pranowo, R., Sunarso, J., Indraswati, N., \& Ismadji, S. (2009). Performance Of Activated Carbon and Bentonite for Adsorption of Amoxicillin from Wastewater: Mechanisms, Isotherms and Kinetics. Water Research. 43, 2419-2430.

[8] Elmolla, E. S., Chaudhuri, M. (2009). Degradation of Antibiotics Amoxicillin, Ampicillin, Cloxacillin in Aqueous Solution by Photofenton. Journal of Hazard Material. 172, 1476-1481.

[9] Kummerer, (2004). Resistance in the Enviro. Journal of Antimicrobial Chemotherapy, 54, 2.

[10] Talogo, A. S. M. (2014). Pengaruh Waktu Dan Temperatur Penyimpanan Terhadap Tingkat Degradasi Kadar Amoksisilin Dalam Sediaan Suspensi Amoksisilin-Asam Klavulanat.

[11] Frieri, M., Kumar, K., Boutin ., A. (2016). Antibiotic Resistance. Journal of Infection and Public Health, 08, 07.

[12] Page, M. I ., Proctor, P. (1984). Mechanism of $\beta$-Lactam Ring Opening in Cephalosporins. J . Am. Chem. SOC, 106, 3820-3825. 
[13] Page, M, I. (1992). The Chemistry of $\beta$-Lactams. Dordrecht, Belanda: Blackie Academic dan Professional.

[14] Siswodihardjo S. (2017). Kimia Medisinal. Edisi ke 2. Surabaya, Indonesia: Airlangga University Press.

[15] Budiman, Candra, Irawati, Hindarso, Herman. (2008). Kinerja Koagulan PAC dalam Penjernihan Air Sungai Kalimasa Surabaya Menjadi Air Bersih. Widya Teknik, 7, 25-34.

[16] Rachman, S. D., Safari, A., Fajli., Kamara, D. S., Sidik, A., Udin, L. Z., Ishmayana, S. (2016). Produksi Penicillium chrysogenum L112 Dengan Variasi Kecepatan Agitasi Pada Fermentor 1 L. Jurnal Ilmiah Farmasi, 4, 1-6. 